\title{
PEMBERDAYAAN PERTANYAAN 5W+1H DALAM IMPLEMENTASI MODEL PEMBELAJARAN INQUIRY SEBAGAI UPAYA MENINGKATKAN HASIL BELAJAR GEOGRAFI
}

\author{
oleh \\ I Ketut Wirta \\ (Guru SMA Negeri 1 Nusa Penida, Kab. Klungkung)
}

\begin{abstract}
ABSTRAK
Penelitian ini bertujuan meningkatkan hasil belajar Geografi siswa dengan pemberdayaan pertanyaan $5 \mathrm{~W}+1 \mathrm{H}$. Penelitian tindakan ini dilaksanakan di SMA Negeri 1 Nusa Penida. Subjek penelitian ini adalah siswa kelas X IBB2 pada semester ganjil tahun pelajaran 2016/2017 sebanyak 22 orang. Objek penelitian adalah hasil belajar Geografi siswa melalui penerapan model pembelajaran Inquiry dengan pemberdayaan pertanyaan $5 \mathrm{~W}+1 \mathrm{H}$. Penelitian dilaksanakan dalam bentuk siklus, masing-masing siklus terdiri dari empat tahapan kegiatan yakni: perencanaan, pelaksanaan, observasi, dan refleksi. Data diperoleh melalui tes hasil belajar dan penyebaran angket, setelah data terkumpul selanjutnya dianalisis dengan menggunakan teknik deskriptif kualitatif. Hasil Penelitian menunjukan bahwa: (1) Penerapan model pembelajaran Inquiry dengan pemberdayan pertanyaan $5 \mathrm{~W}+1 \mathrm{H}$ dapat meningkatkan hasil belajar siswa kelas X IBB2 SMA Negeri 1 Nusa Penida. Hal ini dapat dilihat dari peningkatan rata-rata skor dari siklus I ke siklus II cukup signifikan, dimana rata-rata hasil belajar yang dicapai 76,50 pada Siklus I meningkat menjadi 81,68 pada siklus II dan (2) Penerapan model pembelajaran Inquiry dengan pemberdayan pertanyaan $5 \mathrm{~W}+1 \mathrm{H}$ dalam pembelajaran geografi dapat meningkatkan tanggapan siswa. Hal ini dibuktikan dengan meningkatnya rata-rata respon siswa, dimana pada siklus I mencapai 60,86 meningkat menjadi 63,36 pada siklus II.
\end{abstract}

Kata Kunci : Model Pembelajaran Inquiri, pemberdayaan 5W+1H, Hasil Belajar Geografi.

\section{PENDAHULUAN}

Pembelajaran Geografi pada jenjang SMA bertujuan agar peserta didik memiliki kemampuan sebagai berikut. 1) memahami pola spasial, lingkungan dan kewilayahan serta proses yang berkaitan, 2) menguasai ketrampilan dasar dalam memperoleh data dan informasi, mengkomunikasikan dan menerapkan pengetahuan geografi, dan 3) menampilkan prilaku peduli terhadap lingkungan 
hidup dan memanfaatkan sumber daya alam secara arif serta memiliki toleransi terhadap kegeografian budaya masyarakat (Kurikulum SMA, 2016). Namun, kenyataan di lapangan menunjukan hal bertolak belakang dari apa yang diuraikan seperti di atas. Berdasarkan hasil pengamatan dan diskusi dengan rekan guru rumpun ilmu sosial terkait dengan kemampuan siswa khususnya kelas $\mathrm{X}$ IBB2 di SMA Negeri 1 Nusa Penida, teridentifikasi masalah-masalah sebagai berikut. 1), sulitnya siswa megaplikasikan teori geografi yang didapat dibangku sekolah pada kehidupan nyata siswa karena dalam pembelajaran hanya mengejar target kurikulum, dan 2) siswa belum mampu menunjukan prilaku peduli terhadap lingkungan hidup, hal ini terbukti dari kesadaran siswa terhadap kelestarian lingkungan masih rendah. Sementara itu, pembelajaran geografi di kelas juga menunjukan masalah sebagai berikut Pertama, gairah belajar siswa dalam pembelajaran geografi masih rendah. Kedua, kinerja (aktivitas belajar) siswa yang teramati masih rendah. Ketiga, hasil belajar geografi siswa rendah, hal ini dapat dilihat dari rata-rata hasil ulangan harian I semester 1 tahun pelajaran 2016/2017 masih di bawah KKM 75 yang ditargetkan dan menunjukan hasil kurang memuaskan, dimana rata-rata hasil belajar hanya mencapai 72,32 , daya serap $72,32 \%$ dan tingkat kentuntasan hanya mencapai $54,55 \%$.

Munculnya masalah seperti yang diuraikan di atas, diduga kuat karena 1) guru masih terpaku pada pembelajaran paradigma lama yaitu lebih dominan mengajar (Tacher center) daripada membelajarkan peserta didik (Student center), sehingga tidak berkembangnya ketrampilan berpikir kritis, kreatif dan inovatif di kalangan siswa, 2) guru kurang melibatkan siswa dalam pembelajaran geografi secara optimal, sehingga siswa menjadi pasif akibatnya siswa tidak terbiasa menyelesaikan masalah dalam kehidupannya dan mengambil keputusan, 3) dikalangan siswa masih muncul kesan materi geografi bersifat hafalan, abstrak dan kurang menyenangkan, dan 4) guru jarang mengajukan pertanyaan kritis kepada siswa, sehingga siswa merasa tidak tertantang dalam kegiatan pembelajaran dan tidak terbiasa berpikir kritis.

Mengacu pada hasil pengamatan dan diskusi yang dilakukan sebelum penelitian dilakukan di kelas X IBB2 SMA Negeri 1 Nusa Penida yang 
menunjukkan indikasi adanya penurunan baik yang berkaitan dengan kemampuan akedemis maupun sikap terhadap pelajaran khususnya pelajaran geografi. Terkait dengan hal tersebut, adapun upaya yang harus dilakukan pada pembelajaran selanjutnya , adalah: (1) pembelajaran yang sebelumnya cendrung didominasi oleh guru harus ditinggalkan dan diganti dengan kegiatan pembelajaran yang lebih banyak melibatkan dan mengaktifkan siswa sehingga iklim pembelajaran menjadi lebih baik atau kondusif, (2) mengkontekstualkan materi-materi pelajaran geografi sehingga mudah dipahami oleh siswa dengan mengaitkan materi pelajaran pada pengalaman keseharian siswa atau situasi disekitar siswa, 3) lebih banyak mengajukan pertanyaan kepada siswa dengan pemberdayaan pertanyaan $5 \mathrm{~W}+1 \mathrm{H}$ dalam pembelajaran geografi, dan 4) mengimplementasikan model pembelajaran yang mampu menumbuhkan dan meningkatkan rasa ingin tahu siswa, berpikir kristis, analitis dan memperkuat tim sebagai suatu keseluruhan. Terkait dengan uraian di atas, maka dilakukan penelitian tindakan di kelas X IBB2 dengan judul "Pemberdayaan Pertanyaan $\mathbf{5 W}+\mathbf{1 H}$ dalam Implementasi Model Pembelajaran Inquiry Sebagai Upaya Meningkatkan Hasil Belajar Geografi”

Berdasarkan latar belakang dan identifikasi masalah di atas, dapat dirumuskan masalah sebagai berikut. "Apakah dengan pemberdayaan pertanyaan $5 \mathrm{~W}+1 \mathrm{H}$ dalam implementasi model pembelajaran Inquiry dapat meningkatkan hasil belajar Geografi siswa di kelas X IBB2 SMA Negeri 1 Nusa Penida pada tahun pelajaran 2016/2017 ?'Sesuai dengan permasalahan-permasalahan yang telah dirumuskan pada bagian sebelumnya yang akan dicari solusinya, maka tujuan penelitian ini adalah "Meningkatkan hasil belajar siswa pada mata pelajaran Geografi di kelas X IBB2 SMA Negeri 1 Nusa Penida melalaui pemberdayaan pertanyaan $5 \mathrm{~W}+1 \mathrm{H}$ dalam mplementasi model pembelajaran Inquiry".

Untuk menjawab pertanyaan tersebut di atas, digunakan konsep geografi secara jelas menegaskan bahwa yang menjadi objek studi geografi tidak lain adalah geosfer, yaitu permukaan bumi yang hakikatnya merupakan bagian dari bumi yang terdiri atas atmosfer (lapisan udara), litosfer (lapisan batuan, kulit bumi), hidrosfer (lapisan air, perairan), dan biosfer (lapisan kehidupan). Dari 
sekian jumlah dan sistem kewilayahan dan sistem kelingkungan tadi pasti ada persamaan dan perbedaan gejala, bahkan keunikan di wilayah-wilayah atau ekosistem (Sumaatmadja, 2001:11). Mengacu pada uraian di atas, geografi merupakan ilmu pengetahuan yang mempelajari tentang bumi berserta gejalagejala yang terjadi dipermukaan bumi, yang meliputi muka bumi dan prosesproses yang membentuknya, hubungan antara manusia dan lingkungannya serta pertalian antara manusia dengan tempat-tempat yang ada di permukaan bumi.

Belajar merupakan suatu proses perubahan yaitu perubahan tingkah laku sebagai hasil dari interaksi dengan lingkungannya dalam memenuhi kebutuhan hidupnya. Perubahan-perubahan tersebut akan nyata dalam seluruh aspek tingkah laku. Belajar ialah suatu proses usaha yang dilakukan seseorang untuk memperoleh suatu perubahan tingkah laku yang baru secara keseluruhan, sebagai hasil pengalamannya sendiri dalam interaksi dengan lingkungan (Slameto, 2010: 2). Selanjutnya Suprijono (2012: 5) mengatakan bahwa hasil belajar merupakan pola-pola perbuatan, nilai-nilai, pengertian-pengertian, sikap-sikap, apresiasi dan keterampilan yang menghasilkan perubahan dari diri individu yang belajar.

Ahmad Taufik, (2010) menjelaskan bahwa Secara umum proses belajar mengajar yang terjadi di sekolah kita masih berkutat dan menekankan diri pada penguasaan materi (content mastery), bukan penguasaan konsep (conceptual mastery). Anak-anak kita juga jarang, bahkan mungkin tidak pernah, diajak dan dibiasakan dengan pola berpikir tingkat tinggi (high order thinking). Dan yang lebih parah, kita sebagai pendidik secara sengaja maupun tidak sengaja, mungkin tidak pernah menanamkan learn how to learn (belajar untuk mempelajari sesuatu). Karena itu wajar bila anak-anak kita tidak berdaya ketika diminta berpikir dan bukan menjawab soal. Pertanyaan kipling menjadi salah satu analisa pemecah masalah yang baik, yang melibatkan pemikiran investigasi. Menurut Sulaiman, (2013) pertanyaan $5 \mathrm{~W}+1 \mathrm{H}$ adalah singkatan dari "what, who, when, where, why, how," yang dalam bahasa Indonesia menjadi "apa, siapa, kapan, di mana, mengapa, bagaimana."

Pembelajaran Inquiry adalah pembelajaran yang melibatkan siswa dalam merumuskan pertanyaan yang mengarahkan untuk melakukan investigasi dalam 
upaya membangun pengetahuan dan makna baru (Ridwan, 2015:59). Model pembelajaran inquiri menekankan pada proses penyelidikan berbasis pada upaya menjawab pertanyan. Model pembelajaran ini bertumpu pada pengembangan kemampuan berpikir siswa, artinya tujuan yang ingin dicapai dengan model pembelajaran ini bukan sekedar siswa dapat menguasai sejumlah materi pelajaran (teoritis), akan tetapi bagaimana siswa dapat mengembangkan gagasan-gagasan atau ide-ide kreatifnya dalam menghadapi fenomena alam dan sosial yang terjadi dilingkungan sekitarnya. Model pembelajaran ini menjurus ke kegiatan-kegiatan problem solving dan berpikir kritis siswa dalam menghadapi situasi kehidupan nyata.

\section{METODE PENELITIAN}

Penelitian ini dilaksanakan di SMA Negeri 1 Nusa Penida, khususnya di kelas X IBB2 pada semester ganjil tahun pelajaran 2016/2017. SMA Negeri 1 Nusa Penida. Penelitian ini tergolong penelitian tindakan kelas (classroom action research) yang pelaksanaannya direncanakan dua siklus. Tiap siklus terdiri atas empat tahapan penelitian, yaitu: (1) perencanaan tindakan, (2) pelaksanaan tindakan, (3) observasi dan evaluasi, dan (4) refleksi. Sebelum melaksanakan siklus terlebih dahulu diadakan refleksi awal. Desain penelitian ini mengikuti pola yang dikembangkan oleh Kemmis \& Mc. Taggart seperti disajikan pada gambar 3.1 berikut ini. 


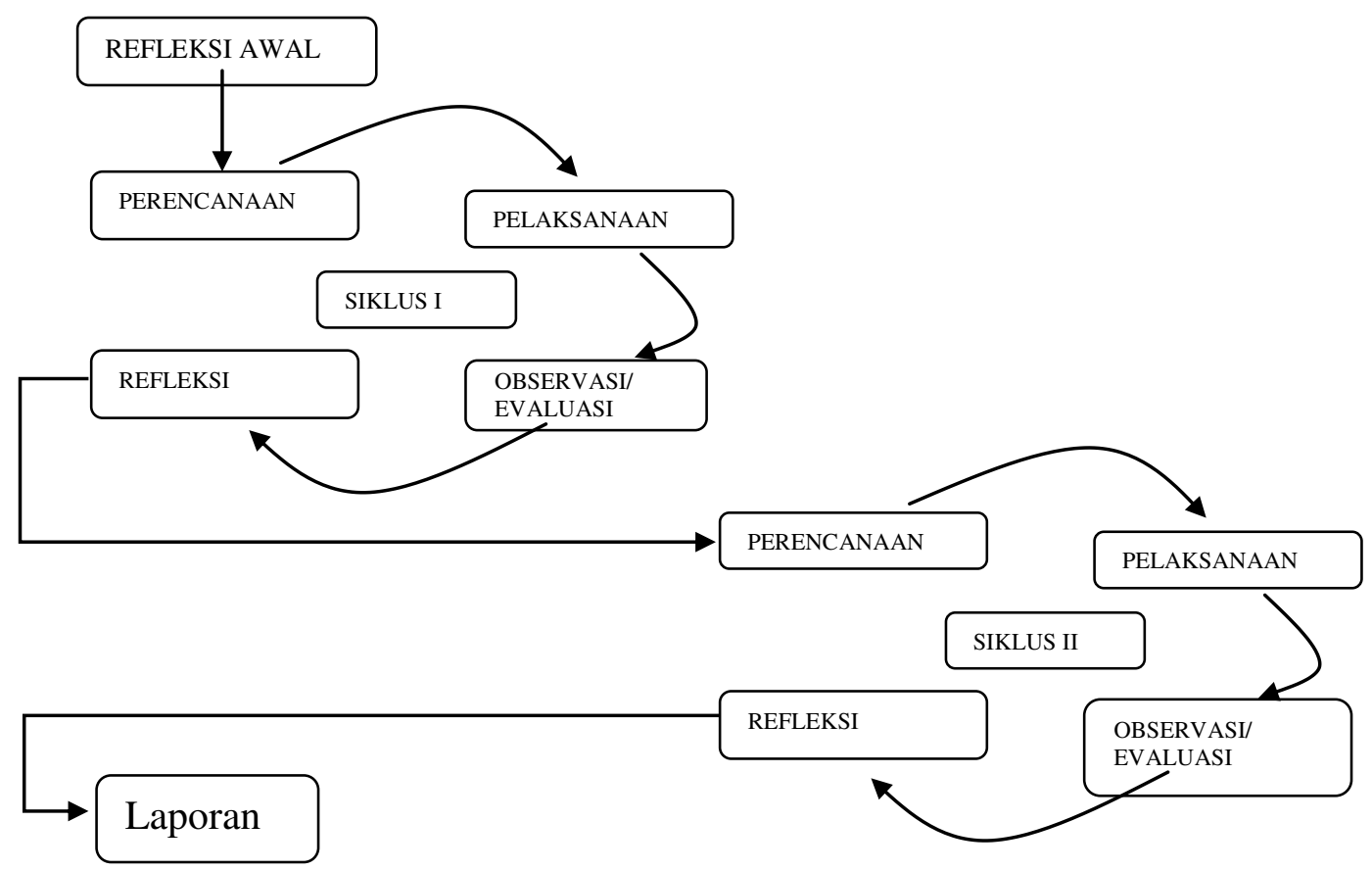

Gambar 3.1 Desain Penelitian (diadaptasi dari Kemmis dan Taggart, 1988)

Teknik pengumpulan data yang digunakan dalam penelitian ini disesuaikan dengan data yang dibutuhkan. Alat yang digunakan untuk memperoleh data tentang respon belajar siswa adalah angket tentang tanggapan siswa baik pada tindakan I maupun tindakan II yang diberikan setelah tes hasil belajar di berikan. Alat yang digunakan untuk memperoleh data tentang aktivitas (aspek fsikomotor) belajar siswa adalah pedoman observasi kinerja siswa baik pada tindakan I maupun tindakan II. Untuk mengukur hasil belajar Geografi siswa digunakan instrument tes hasil belajar Geografi. Tes hasil belajar Geografi ini berupa soal Esay sebanyak 5 soal. Tes ini disusun oleh peneliti dengan berpedoman pada kurikulum 2013. Data hasil belajar yang mencakup aspek kognitif siswa dianalisis secara deskriptif.

\section{HASIL DAN PEMBAHASAN}

\section{a. Evaluasi Hasil Belajar Siswa Pada Siklus I}

Rata-rata hasil belajar Geografi yang dicapai siswa mengalami peningkatan yang cukup tinggi jika dibandingkan dengan tes awal (test pra siklus) 
yang dilakukan sebelumnya. Hal tersebut dapat dilihat dari rata-rata yang diperoleh oleh siswa mencapai 76,50 dan daya serap mencapai 76,50\% dengan tingkat ketuntasan materi mencapai $68,18 \%$. Secara lebih rinci perolehan nilai dari siswa adalah sebagai berikut.

Tabel 4.1 Hasil Belajar Geografi Kelas X IBB2

Tahun Pelajaran 2016/2017

\begin{tabular}{|c|c|c|c|c|}
\hline No & Rentang nilai & Kategori & frekuensi & Prosentase (\%) \\
\hline 1 & $90 \%-100 \%$ & Sangat Tinggi & 3 & $13,64 \%$ \\
\hline 2 & $80 \%-89 \%$ & Tinggi & 4 & $18,18 \%$ \\
\hline 3 & $65 \%-79 \%$ & Cukup tinggi & 13 & $59,09 \%$ \\
\hline 4 & $55 \%-64 \%$ & Rendah & 1 & $4,55 \%$ \\
\hline 5 & $0-54 \%$ & Sangat Rendah & 1 & $4,55 \%$ \\
\hline & Total & & $\mathbf{2 2}$ & $100,00 \%$ \\
\hline
\end{tabular}

Hasil analisis data hasil belajar pada aspek fsikomotor menunjukan bahwa rata-rata yang dicapai siswa mencapai 78,60 dengan tingkat ketuntasan. Untuk lebih jelasnya dapat dilihat pada tabel berikut.

Tabel 4.2 Hasil Belajar Geografi Siswa Kelas X IBB2 pada aspek

Fsikomotor Tahun Pelajaran 2016/2017

\begin{tabular}{|c|c|c|c|c|}
\hline No & Rentang nilai & Kategori & frekuensi & $\begin{array}{c}\text { Prosentase } \\
(\mathbf{\%})\end{array}$ \\
\hline 1 & $91-100$ & SB (Sangat Baik) & 3 & $13,64 \%$ \\
\hline 2 & $75-90$ & B (Baik) & 13 & $59,09 \%$ \\
\hline 3 & $60-74$ & C (Cukup) & 6 & $27,27 \%$ \\
\hline 4 & $\leq 59$ & K (Kurang) & 0 & $0,00 \%$ \\
\hline & Total & & $\mathbf{2 2}$ & $100,00 \%$ \\
\hline
\end{tabular}

Skor sikap siswa diperoleh dari hasil observasi sebanyak tiga kali pada siklus I yang disajikan pada lampiran. Berdasarkan hasil analisis yang diperoleh nilai rata-rata afektif siswa sebesar 76,99 yang tergolong kategori cukup dengan tingkat ketuntasan 68,18 . Sebaran nilai afektif siswa pada siklus I disajikan pada Tabel 4.3. 
Tabel 4.3 Hasil Belajar Geografi Siswa Kelas X IBB2 pada aspek Afektif Tahun Pelajaran 2016/2017

\begin{tabular}{|c|c|c|c|c|}
\hline No & Rentang nilai & Kategori & frekuensi & $\begin{array}{c}\text { Prosentase } \\
(\mathbf{\%})\end{array}$ \\
\hline 1 & $91-100$ & SB (Sangat Baik) & 0 & $0,00 \%$ \\
\hline 2 & $75-90$ & B (Baik) & 15 & $68,18 \%$ \\
\hline 3 & $60-74$ & C (Cukup) & 7 & $31,82 \%$ \\
\hline 4 & $\leq 59$ & K (Kurang) & 0 & $0,00 \%$ \\
\hline & Total & & $\mathbf{2 2}$ & $100,00 \%$ \\
\hline
\end{tabular}

Berdasarkan analisis dan refleksi terhadap jalannya pembelajaran pada tindakan pertama ini, maka aspek-aspek yang perlu diperbaiki pada pembelajaran selanjutnya adalah sebagai berikut. 1) Mengarahkan siswa agar lebih banyak melakukan pengamatan dan menggali informasi melalui membaca buku paket dan buku penunjang yang berkaitan dengan materi mata pelajaran Geografi serta lebih banyak belajar dilapangan secara langsung, 2) Memberikan pengarahan secara umum tentang langkah-langkah dalam melaksanakan penerapan model pembelajaran Inquiry dengan pemberdayaan pertanyaan $5 \mathrm{~W}+1 \mathrm{~W}$ dan membangkitkan minat dan partisifasi siswa secara menyeluruh dalam kegiatan pembelajaran geografi, 3) Memberikan motivasi kepada siswa yang memiliki kemampuan rata-rata menengah kebawah agar tidak merasa malu untuk bertanya kepada anggota kelompoknya yang lebih pintar, 4) Mengupayakan tersedianya media atau sarana dan prasarana yang lebih baik dan kompleks sebagai penunjang pembelajaran misalnya Peta persebaran tanah, LKS dan buku-buku penunjang lainnya, dan 5) Memberikan penghargaan bagi kelompok/siswa yang berprestasi sehingga menjadi lebih bersemangat dalam kegiatan pembelajaran.

\section{b) Evaluasi Hasil Belajar Siswa Pada Siklus II.}

Berdasarkan analisis data yang telah dilakukan terhadap data hasil belajar Geografi siswa kelas X IBB2, menunjukan bahwa rata-rata yang dicapai siswa sudah di atas KKM 75 dan mengalami peningkatan yang 
signifikan jika dibandingkan dengan tes siklus I yang dilakukan sebelumnya. Hal tersebut dapat dilihat dari rata-rata yang diperoleh oleh siswa mencapai 81,68 dan daya serap mencapai $81,68 \%$ serta ketuntasan materi mencapai $81,82 \%$. Lebih rinci perolehan nilai dari siswa adalah sebagai berikut.

Tabel 4.5 Hasil Belajar Geografi Kelas X IBB2 siklus II

Tahun Pelajaran 2016/2017

\begin{tabular}{|c|c|c|c|c|}
\hline No & Rentang nilai & Kategori & frekuensi & Prosentase (\%) \\
\hline 1 & $90 \%-100 \%$ & Sangat Tinggi & 10 & $45,45 \%$ \\
\hline 2 & $80 \%-89 \%$ & Tinggi & 3 & $13,64 \%$ \\
\hline 3 & $65 \%-79 \%$ & Cukup Tinggi & 6 & $27,27 \%$ \\
\hline 4 & $55 \%-64 \%$ & Rendah & 0 & $0,00 \%$ \\
\hline 5 & $0-54 \%$ & Sangat Rendah & 3 & $13,64 \%$ \\
\hline & Total & & $\mathbf{2 2}$ & $100,00 \%$ \\
\hline
\end{tabular}

Sementara itu, dari analisis data hasil belajar pada aspek fsikomotor menunjukan rata-rata yang dicapai siswa adalah 85,42 dengan tingkat ketuntasan 95,45\%. Untuk lebih jelasnya dapat dilihat pada tabel berikut.

Tabel 4.6 Hasil Belajar Geografi Siswa Kelas X IBB2 pada aspek

Fsikomotor Tahun Pelajaran 2016/2017

\begin{tabular}{|c|c|c|c|c|}
\hline No & Rentang nilai & Kategori & frekuensi & Prosentase (\%) \\
\hline 1 & $91-100$ & SB (Sangat Baik) & 5 & $22,73 \%$ \\
\hline 2 & $75-90$ & B (Baik) & 16 & $72,73 \%$ \\
\hline 3 & $60-74$ & C (Cukup) & 1 & $4,55 \%$ \\
\hline 4 & $\leq 59$ & K (Kurang) & 0 & $0,00 \%$ \\
\hline & Total & & $\mathbf{2 2}$ & $100,00 \%$ \\
\hline
\end{tabular}

Sedangkan hasil analisis yang diperoleh nilai rata-rata afektif siswa sebesar 84,94 yang tergolong kategori cukup baik dengan tingkat ketuntasan 90,91. Sebaran nilai afektif siswa pada siklus II disajikan pada Tabel 4.7. 
Tabel 4.7 Hasil Belajar Geografi Siswa Kelas X IBB2 Pada Aspek

Afektif Tahun Pelajaran 2016/2017

\begin{tabular}{|c|c|c|c|c|}
\hline No & Rentang nilai & Kategori & frekuensi & $\begin{array}{c}\text { Prosentase } \\
(\boldsymbol{\%})\end{array}$ \\
\hline 1 & $91-100$ & SB (Sangat Baik) & 7 & $31,82 \%$ \\
\hline 2 & $75-90$ & B (Baik) & 14 & $63,64 \%$ \\
\hline 3 & $60-74$ & C (Cukup) & 1 & $4,55 \%$ \\
\hline 4 & $\leq 59$ & K (Kurang) & 0 & $0,00 \%$ \\
\hline & Total & & $\mathbf{2 2}$ & $100,00 \%$ \\
\hline
\end{tabular}

Berdasarkan analisis dan refleksi terhadap jalannya proses pembelajaran pada tindakan kedua ini, maka aspek-aspek yang perlu diperbaiki pada pembelajaran berikutnya adalah sebagai berikut. 1) Mengupayakan tersedianya media pembelajaran atau sarana dan prasarana penunjang pembelajaran misalnya CD Pembelajaran, LKS dan buku-buku penunjang sehingga proses pembelajaran menjadi lebih menyenangkaan dan lebih maksimal, 2) Mengarahkan siswa agar lebih banyak membaca buku paket dan buku penunjang serta memamfaatkan internet yang berkaitan dengan mata pelajaran geografi serta lebih banyak belajar dilapangan secara langsung, 3) Mengefisienkan waktu dalam pembelajaran dengan menggunakan Inquiry sehingga target kurikulum dapat tercapai, 4) Mengefektifkan ketrampilan bertanya untuk memancing siswa berpikir kritis

Implikasi dari penerapan model pembelajaran inkuiry yang benar sesuai teori yang ada adalah terjadi peningkatan rata-rata hasil belajar siswa pada siklus I dapat diupayakan dan mencapai rata-rata 76,50. Namun rata-rata tersebut belum maksimal karena hanya 15 siswa memperoleh nilai di atas KKM sedangkan yang lainnya belum mencapai KKM. Sedangkan prosentase ketuntasan belajar mereka baru mencapai $68,18 \%$. Hal tersebut terjadi akibat penggunaan model pembelajaran Inquiry dengan pemberdayan pertanyaan $5 \mathrm{~W}+1 \mathrm{H}$ belum maksimal dapat dilakukan disebabkan penerapan model tersebut baru dicobakan sehingga guru masih belum mampu melaksanakannya sesuai alur teori yang benar. Pada siklus ke II perbaikan hasil belajar siswa diupayakan lebih maksimal dengan peneliti membuat perencanaan yang lebih baik, menggunakan alur dan teori dari 
model pembelajaran Inquiry dengan benar dan lebih maksimal. Peneliti giat memotivasi siswa agar giat belajar, memberi arahan-arahan, menuntun mereka untuk mampu menguasai materi pelajaran pada mata pelajaran Geografi lebih optimal. Akhirnya dengan semua upaya tersebut peneliti mampu meningkatkan hasil belajar siswa pada siklus II menjadi rata-rata 81,68, dengan ketuntasan belajar mencapai $81,82 \%$.Upaya-upaya yang maksimal tersebut menuntun kepada penelitian bahwa model pembelajaran inkuiri mampu meningkatkan hasil belajar siswa.

Terjadinya peningkatan hasil belajar siswa di kelas X IBB2 SMA Negeri 1 Nusa Penida di pengaruhi oleh faktor-faktor sebagai berikut. 1) kualitas pembelajaran yang dilakukan oleh guru dari setiap tindakan, secara kualitas menunjukan peningkatan, 2) siswa semakin mengerti dan akrab dengan model pembelajaran yang diterapkan oleh guru, 3) dengan pola belajar secara kelompok yang bersifat tutor sebaya dan berbasis penemuan, memungkinkan siswa untuk banyak belajar karena disamping apa yang diperoleh dari guru mereka juga memperkaya diri dengan pengalaman sehingga pemahaman dan pengetahuan yang diperoleh dari belajar pada siswa yang lebih pintar pada saat mereka belajar berkelompok, 4) dengan dijelaskannya tujuan pembelajaran oleh guru sebelum pembelajaran dilaksanakan, siswa dapat memahami tentang target pembelajaran khususnya tentang materi yang harus dimengerti selama pembelajaran, sehingga dapat membangkitkan minat belajar siswa dan 5) dalam proses pembelajaran dengan menggunakan model pembelajaran inquiry a si bolang, siswa menjadi subyek pembelajaran dan mengkaitkan pengalaman belajar mereka dari apa yang dilakukan sehingga lebih cepat menjadi paham. Dari apa yang dipaparkan seperti di atas, tampak sesuai dengan apa yang diungkapkan oleh Frederik (1991) dalam Ngalimun, 2016:68) yang menyatakan bahwa pembelajaran berbasis Inquiry mempunyai implikasi yang hebat dalam setiap kelas. karena model pembelajaran ini memungkinkan siswa membangun jalur discovery dan investigasinya melalui pengalaman kelas dan perpustakaan yang membimbing mereka memahami konsep-konsep yang bernilai. Hal ini juga senada dengan temuan-temuan dari sebuah penelitian yang lainnya yang menyatakan peneran model pembelajaran 
inquiry efektif meningkatkan hasil belajar siswa begitujuga dengan hasil penelitian dengan pemberdayan pertanyaan $5 \mathrm{~W}+1 \mathrm{H}$ dalam pembelajaran juga meningkatkan hasil belajar siswa. Dengan demikian hipotesis yang berbunyi “ Penerapan model pembelajaran Inquiry ala Sibolang dapat meningkatkan hasil belajar dan tanggapan siswa kelas X IBB2, dapat terjawab.

\section{SIMPULAN DAN REKOMENDASI}

Berdasarkan hasil penelitian dan pembahasan dari siklus I dan II pada penelitian tindakan yang dilaksanakan di kelas X IBB2 SMA Negeri 1 Nusa Penida dapat disimpulkan bahwa penerapan model pembelajaran Inquiry dengan pemberdayan pertanyaan $5 \mathrm{~W}+1 \mathrm{H}$ dapat meningkatkan hasil belajar siswa kelas $\mathrm{X}$ IBB2 SMA Negeri 1 Nusa Penida. Hal ini dapat dilihat dari peningkatan rata-rata skor dari siklus I ke siklus II cukup signifikan, dimana rata-rata hasil belajar yang dicapai 76,50 pada Siklus I meningkat menjadi 81,68 pada siklus II.

Berdasarkan hasil Penelitian dan analisis data, direkomendasikan sebagai berikut: 1) Bagi praktisi pendidikan yang ingin melaksanakan penelitian tindakan kelas dengan model pembelajaran Inquiry diharapkan memperhatikan hasil refleksi dalam penelitian tindakan kelas ini, yang meliputi a) pentingnya ketersediaan sarana penunjang pembelajaran berupa buku-buku pelajaran dan alatalat penunjang lainnya, b) penyesuaian kegiatan belajar dengan alokasi waktu yang tersedia, c) perancangan pelaksanaan kegiatan belajar dan perangkat pembelajaran yang baik sehingga pembelajaran menjadi efektif, dan lebih mengefektifkan kegiatan pembelajaran dengan pemberdayan pertanyaan $5 \mathrm{~W}+1 \mathrm{H}$, dan 2) Model pembelajaran Inquiry dengan pemberdayan pertanyaan $5 \mathrm{~W}+1 \mathrm{H}$ geografi cocok diterapkan dalam pembelajaran geografi karena sesuai dengan tuntutan Kurikulum 2013 yang menekankan proses pendidikan pada pembelajaran geografi melalui pelaksanaan pembelajaran ilmiah dan proses pembelajaran yang dikaitkan dengan kehidupan/pengalaman sehari-hari siswa. 


\section{DAFTAR PUSTAKA}

Abdulah Sani Ridwan, 2015. Pembelajaran saintifik Untuk Implementasi Kurikulum 2013. Jakarta : Bumi Aksara

Sanjaya, Wina. 2010. Strategi Pembelajaran Berorientasi Standar Proses Pendidikan. Jakarta: Kencana Prenada Media Group.

Sardiman. 2012. Interaksi dan Motivasi Belajar Mengajar. Jakarta: PT RajaGrafindo Persada.

Slameto, 1995. Belajar dan factor-faktor yang mempengaruhi. Jakarta : Rineka Cipta.

Sulaeman,2010. 6 Pertanyaan Penting Untuk Menganalisa Masalah $(5 \mathrm{~W}+1 \mathrm{H})$. Artikel. http://id.wikipedia.org/wiki/Berita \& http://satriamadangkara.com/definisi-berita-dan-penjelasan-unsur-5wIh (Diakses tanggal 15 Agustus 2016)

Sumaatmadja, Nursid. 2001. Metodelogi Pengajaran Geografi. Jakarta: PT Bumi Aksara.

Suprijono, Agus. 2013. Cooperatif Learning. Yogyakarta: Pustaka Pelajar.

Taupik, Ahmad, 2010. Metode 5W+1H. (Online). Sumber :http://id.wikipedia.org/wiki/Berita \& http://satriamadangkara.com/defi nisi-berita-dan-penjelasan-unsur-5w-1h/ (Diakses tanggal 15 Agustus 2016)

Trianto. 2012. Mendesain Model Pembelajaran Inovatif-Progresif. Kencana Prenada Media Group. Jakarta. 